\title{
АКАДЕМІЧНА МОБІЛЬНІСТЬ ЯК ФАКТОР ПІДВИЩЕННЯ КОНКУРЕНТОЗДАТНОСТІ ЗАКЛАДУ ВИЩОЇ ОСВІТИ
}

У статті проаналізовано академічну мобільність та міжнародну діяльність у сучасному технічному університеті та їхній вплив на підвищення конкурентоздатності закладу вищої освіти в українських та світових рейтингах. Визначені найбільи значимі умови, котрі здатні забезпечити ефективний поступ університету на тлі глобалізаційних прочесів у вищій освіті. Окрему увагу приділено потенційним бар'єрам, які можуть стати на заваді ефективній реалізаиії академічної мобільності.

На прикладі діяльності Національного технічного університету «Харківський політехнічний інститут» розглянуто прочес планомірного та иілеспрямованого налагодження відносин з академічними спільнотами зарубіжних краӥн. Приділено увагу важливості участі університету у світових рейтингах QS World University Rankings, The Times Higher Educational Ranking, THE WUR mошо. Участь у ичих та інших загальновизнаних світовою спільнотою університетських рейтингах є важливим кроком в ефективній реалізації програм академічної мобільності, оскільки багато країн використовують адміністративні важелі для регулювання потоків студентства - визнають лише дипломи ЗВО-учасників таких рейтингів, часто надають державні стипендіі чи інші преферениії.

Окреме питання, котре висвітлено на сторінках публікації - вдосконалення мовної підготовки науково-педагогічних прачівників. Обірунтовано доцільність збільшення кількості викладачів, які вільно володіють англійською мовою, та збільшення англомовних програм бакалавра, магістра та доктора філософії. Ці питання взаємопов'язані, тож інтенсифікація роботи з отримання викладачами університету сертифікатів, котрі підтверджують знання англійської мови на рівні В2 чи вище буде сприяти розвитку англомовних програм на кількісному, а головне - на якісному рівні. Підвищення якості володіння іноземними мовами науково-педагогічними працівниками може відбуватися як унаслідок реалізації виключно внутрішніх програм, так $i$ завдяки участі в різноманітних мовних програмах таких установ, як Британська Рада, у програмах академічного обміну.

Ключові слова: академічна мобільність, міжнародна діяльність, міжнародна співпраця, міжкультурна комунікація, мотивація, полікультурне середовище, якість освіти, конкурентоздатність закладів вищої освіти.

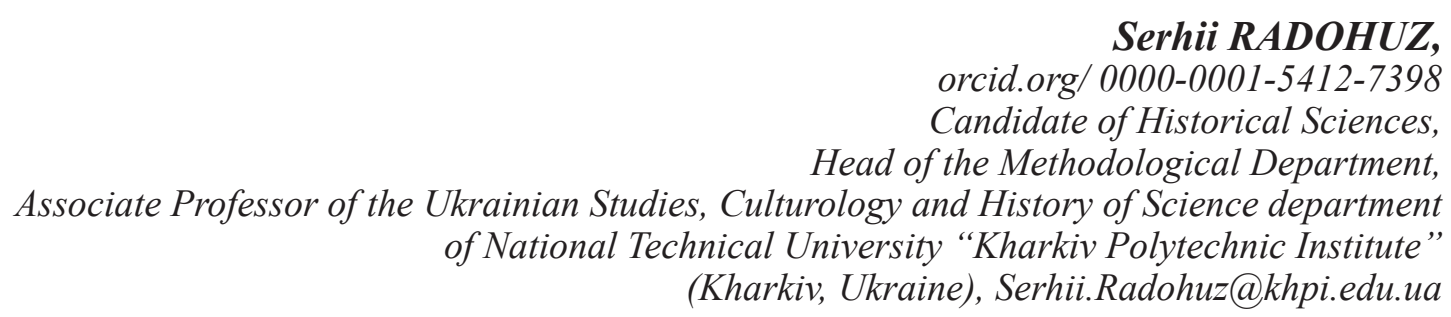

Tetiana NETETSKA, orcid.org/ 0000-0001-5298-0563 Associate Professor of the Cross-Cultural Communication and Foreign Languages Department of National Technical University "Kharkiv Polytechnic Institute"

(Kharkiv,Ukraine), tannett29@gmail.com 


\section{ACADEMIC MOBILITY AS A WAY OF THE COMPETITIVENESS OF HIGHER EDUCATION INSTITUTIONS INCREASING}

The article analyzes academic mobility and international activities in a modern technical university and their impact on improving the competitiveness of higher education institutions in the Ukrainian and world rankings. The most significant conditions that can ensure the effective progress of the university against the background of globalization processes in higher education are identified. Particular attention is paid to potential barriers that may hinder the effective implementation of academic mobility.

The process of systematic and purposeful establishment of relations with academic communities of foreign countries is considered on the example of the activity of the National Technical University "Kharkiv Polytechnic Institute". Attention is paid to the importance of the university's participation in the world rankings QS World University Rankings, The Times Higher Educational Ranking, THE WUR, etc. Participation in these and other universally recognized university rankings is an important step in the effective implementation of academic mobility programs, as many countries use administrative levers to regulate student flows - recognizing only diplomas from universities participating in such rankings, often providing government scholarships or other preferences.

A separate issue covered on the pages of the publication is the improvement of language training of scientific and pedagogical workers. The expediency of increasing the number of teachers who are fluent in English and increasing the English-language programs of bachelor, master and doctor of philosophy is substantiated. These issues are interrelated, so intensifying the work of obtaining university certificates confirming knowledge of English at the level of B2 or higher, will contribute to the development of English-language programs on a quantitative and, most importantly, qualitative level. Improving the quality of foreign language proficiency by research and teaching staff can occur as a result of the implementation of exclusively internal programs, and through participation in various language programs of institutions such as the British Council, academic exchange programs.

Key words: academic mobility, international activity, international cooperation, cross-cultural communication, multicultural environment, education quality, higher education competitiveness.

Постановка проблеми. Сьогодні все частіше міжнародна академічна мобільність студентів стає невід’ємною частиною освітнього процесу. За деякими прогнозами, до 2025 р. кількість студентів, котрі будуть навчатись за кордоном, може досягти 8 мільйонів осіб (Altbach, 2016: 81-105). На це направлена, зокрема, політика Свропейського Союзу та ключова ідея Болонського процесу, який був створений заради максимальної гармонізації академічних структур та програм i, як наслідок, - зростання учасників процесу міжнародної академічної мобільності. На сьогодні значна частка 3ВО приєдналась до цієї ініціативи та перейшла на систему, де міжнародна мобільність студентів є невід'ємним складником освітнього процесу. Україна - не виняток. Вітчизняні ЗВО щорічно приділяють усе більшу увагу міжнародному академічному обміну студентів. I не дивно, адже саме академічна мобільність є одним із ключових напрямів інтеграції українських закладів вищої освіти (ЗВО) до міжнародного освітнього простору.

Розуміючи вигоди, які несе в собі розвиток мобільності для зростання конкурентоспроможності ЗВО на міжнародній арені, з новими силами почалась підтримка розвитку академічної мобільності, вбачаючи в ній інструмент й одне із завдань Болонського процесу. Під ним розуміється процес формування єдиного європейського науковоосвітнього простору. 3 іншого боку, глобальні процеси в системі вищої освіти не стоять на місці й постійно оновлюються. Не дарма навіть Рада управління «Великою Хартією університетів» визнала, що з 1988 року, коли було їі проголошено, в академічному середовищі відбулось достатньо змін та вказала на доцільність унесення змін до Великої Хартії, фінальний проєкт якої буде оприлюднено в березні 2020 року (Magna Charta, 2020). Підписання заплановане на 17-18 вересня 2020 року. Іншою ініціативою став ціннісно-орієнтований проєкт Living Values, головна мета якого - залучити всю університетську спільноту до досягнення місії університету. Пілотування останнього одночасно проходило в десяти університетах, розташованих у дев'яти країнах та принесло цікавий досвід щодо включення всіх стейкхолдерів у процес формування університетських цінностей (Living Values, 2019).

Аналіз досліджень. Питання академічної мобільності знайшли своє відображення у Великій хартії Університетів (Magna Charta Universitatum), Сорбонській та Болонській деклараціях (The Bologna Declaration; Wit Hans, 2000), Берлінському комюніке. Академічна мобільність стала відповіддю на внутрішню потребу особи реалізувати свій інтелектуальний потенціал. Не дарма все частіше спостерігається рух студентства в більш розвинені (в економічному плані) країни (Altbach, 2016: 105). Цьому процесу сприяють усе більш відкриті кордони. Урешті-решт академічна мобільність дозволяє студентству самостійно формувати свою освітню траєкторію. 
Водночас процеси глобалізації сприяли тому, що якщо раніше в межах освітніх стандартів студенти могли обирати певні предмети чи курси, то тепер їхній вибір став значно ширшим і дозволяє обирати зокрема й навчальні заклади.

За словами В. Галичина, академічна мобільність стала одним із найбільш ефективних інструментів підвищення якості людського капіталу (Галичин, 2009: 377). Глобалізаційні процеси привели до стрімкого зростання обміну академічної спільноти між країнами. I хоча для країн, які розвиваються, це іноді несе певні негативні фактори, неможливо не погодитись, що такий броунівський рух сприяє розширенню і зміцненню міжнаціонального співробітництва у сфері науки і техніки. Окрім того, посилення конкуренції змушує «підтягнути» національні освітні системи. Зрештою, вже класичний вислів Льюїса Керрола про те, що «тут потрібно бігти з усіх ніг, щоб тільки залишатись на місці, а щоб кудись потрапити, треба бігти хоча $б$ удвічі швидше!» в науково-освітній сфері особливо актуальний.

Водночас саме поняття академічної мобільності дослідники розцінюють по-різному. Так, наприклад, О. Мартиненко визначає академічну мобільність як можливість для студентів та науково-педагогічних працівників 3ВО переміщатись 3 одного ЗВО в інший із метою обміну досвідом та отримання можливостей, які 3 тих чи інших причин залишаються недоступними у стінах рідної Alma Mater (Мартиненко, 2008: 65-75). Інші автори під академічною мобільністю розуміють період навчання студента у країні, громадянином якої він не є (Бриньов, Чуянов, 2001: 31-32). Ключовими факторами цього підходу є обмеженість у часі та обов'язкове повернення студента в рідну країну після завершення навчання.

Мета статті - розглянути досвід розвитку академічної мобільності в Національному технічному університеті «Харківський політехнічний інститут» (НТУ «ХПІ»). Дослідити фактори, які сприяли її піднесенню.

Виклад основного матеріалу. Академічна мобільність $є$ одним із пріоритетних напрямів діяльності закладів вищої освіти. Однак серед завдань, котрі стоять перед нею, метою $є$ не лише підвищення якості освіти, а й поліпшення взаєморозуміння між різними народами й культурами, виховання нового покоління, підготовленого до життя й роботи в міжнародному інформаційному співтоваристві. Значний внесок у міжкультурний діалог робить один із найбільших ЗВО України, яким є Національний технічний університет «Харківський політехнічний інститут».
Прийом іноземних громадян та розподіл їх за навчально-науковими інститутами й факультетами 3 метою надання освітніх послуг у НТУ «ХПІ» здійснює деканат факультету міжнародної освіти (ФМО). Значна частина вступників-іноземців проходять довузівську підготовку, яка має два складники - інтенсивна мовна підготовка та вивчення навчальних предметів, що мають ключове значення для подальшого навчання іноземців у ЗВО відповідного профілю. Такий довузівський «інтенсив» забезпечується кафедрами природничих та гуманітарних наук, котрі входять до складу ФМО.

Протягом п'яти років в університеті реалізовувалась комплексна програма зі збільшення контингенту іноземних студентів та покращення якості їх підготовки. Вона охоплювала: покращення позицій університету у світових рейтингах; збільшення кількості студентів основних факультетів та довузівської підготовки, які навчаються англійською мовою; покращення умов мешкання студентів у гуртожитках; освоєння нових сегментів світового ринку освітніх послуг та активізація роботи на традиційних.

Покращення позицій університету у світових рейтингах відіграє суттєву роль у збільшенні контингенту студентів, оскільки уряди низки країн запровадили адміністративні важелі для того, щоб стимулювати студентів навчатись в університетах, котрі входять до визнаних світових рейтингів. Так, наприклад, уряд Єгипту спрощує процедуру визнання дипломів, отриманих в іноземних університетах, котрі входять до 1000-і найкращих QS World University Rankings. Уряд Туреччини сплачує стипендію студентам, які навчаються в іноземних університетах, що входять до топ 1000 QS World University Rankings. Уряд Туркменістану визнає дипломи студентів гуманітарних та економічних спеціальностей лише тих університетів, котрі входять до The Times Higher Educational Ranking.

Послідовна робота в цьому напрямі дозволила НТУ «ХПІ» ввійти до трійки кращих українських ЗВО світового рейтингу QS World University Rankings 2020. Варто зауважити, що університету вдалось не лише потрапити до рейтингу, але й поліпшити свої показники. Наразі Університет займає 651-700 місце, що є найкращим показником серед технічних ЗВО України. За версією британського агентства The Times Higher Education, університет увійшов до щорічного світового рейтингу дослідницьких університетів The Times Higher Education World University Rankings 2020, ставши одним із двох технічних вузів України, які потрапили в цей престижний світовий рейтинг, зайнявши позицію 1001+. НТУ «ХПІ», бувши 
учасником цього престижного рейтингу - ТНЕ WUR 2020 року, зайняв місце 801+ у двох категоріях: «фізичні науки» й «техніка й технології». Таким чином, Національний технічний університет «Харківський політехнічний інститут» став другим українським 3ВО в обох категоріях.

Для збільшення кількості студентів, які навчаються англійською мовою, та покращення якості ïх підготовки протягом 5 років у НТУ «ХПІ» вживалися заходів, спрямованих на таке: збільшення кількості викладачів, котрі володіють англійською мовою на рівні В2; збільшення кількості спеціальностей, на яких підготовка проводиться виключно англійською мовою; поліпшення матеріально-технічної бази кафедр, що проводять підготовку іноземних студентів англійською мовою.

Протягом кількох останніх років методичний відділ університету організовує безкоштовні інтенсивні курси $з$ англійської мови. Відбір учасників проходить на конкурсній (грантовій) основі. Завдяки такому підходу щорічно формується 4-5 груп серед найбільш активних та вмотивованих молодих викладачів, котрі навчаються за цими курсами. Іншою успішною ініціативою стало преміювання викладачів університету за отримання сертифікату, що підтверджує знання англійської мови на рівні В2. Окрім того, університет уклав низку угод із комерційними фірмами. Таким чином, працівники університету, які бажають покращити свою мовну підготовку, можуть навчатись за зниженими «корпоративними» цінами.

У 2017-2018 роках в університеті реалізовувалась програма Британської Ради 3 дистанційного вивчення англійської мови. У 2017 році англійську мову вивчали понад 100 викладачів університету. За угодою між НТУ «ХПІ» та Австрійської службою академічних обмінів, у 2017-2018 навчальному році в НТУ «ХПІ» працював австрійський викладач-носій німецької мови. Угода буде діяти протягом 5 років. У 2018 році НТУ «ХПІ» за підтримки Департаменту міжнародного співробітництва Харківської міської ради приєднався до європейської освітньої платформи Lingtwins (Англія), яка дозволяє студентам, викладачам та науковцям підвищувати рівень знань іноземних мов.

Шляхом інтенсифікації роботи 3 отримання викладачами університету сертифікатів, які підтверджують знання англійської мови на рівні В2, було забезпечено успішне проходження ліцензування для підготовки іноземних студентів на 30 спеціальностях.

Унаслідок описаних вище заходів в університеті на всіх факультетах та в навчально-наукових інститутах спостерігається тенденція до збіль- шення кількості спеціальностей, на яких викладання здійснюється англійською мовою. Водночас загальна кількість спеціальностей збільшилась із 3 спеціальностей у 2015 році до 22 спеціальностей у 2019 році.

Також проводилось планомірне освоєння нових сегментів світового ринку освітніх послуг у Сгипті, Марокко, Алжирі та Туреччині. Активізація традиційних сегментів відбувалась в Азербайджані та Узбекистані.

У березні 2018 року делегація НТУ«ХПІ» відвідала Єгипет. У приміщенні Посольства України в Сгипті відбулась презентація університету. Результатом візиту стало створення в Сгипті профорієнтаційної мережі НТУ «ХПІ», до якої були залучені три фірми, котрі мають плідні зв'язки 3 директорами шкіл та державними установами.

У липні 2018 року помічник ректора НТУ «ХПІ» по роботі зі студентами із країн Близького Сходу Іссам Шахін відвідав Королівство Марокко. За підсумками зустрічі з ректором університету Ibn Zohr (UIZ) (м. Агадір) професором Омаром Халлі (Omar Halli) між НТУ «ХПІ» та UIZ був підписаний меморандум, який дозволив провадити академічний обмін між студентами й викладачами, спільні дослідження та конференції, програми культурного обміну. Також були зроблені кроки до налагодження співпраці між НТУ «ХПІ» й вищими навчальними закладами Алжиру та обговорені проблемні питання залучення абітурієнтів до вступу в НТУ «ХПІ». Результати цих зустрічей були відображені, зокрема, в ЗМІ (Рис. 1).

Основу для збільшення кількості студентів із Туреччини було закладено у травні 2019 році під час візиту проректора Геннадія Хрипунова до Стамбулу. Було проведено зустрічі із двома авторитетними турецькими фірмами BATI AKDENIZ та ATLAS PRIVATE EDUCATIONAL SERVICES, які протягом року співпрацювали 3 міжнародним факультетом у галузі залучення до навчання в НТУ «ХПІ» молоді з Туреччини. Про плідність такого співробітництва свідчить той факт, що вже того року 130 турецьких студентів, почали проходити довузівську підготовку та навчатися на інженерних спеціальностях Національного технічного університету «Харківський політехнічний інститут». Особливістю навчання турецьких студентів $€$ їх прагнення здобувати освіту англійською мовою. Турецькі представники високо оцінило зусилля НТУ «ХПІ» зі збільшення кількості спеціальностей, на яких викладання здійснюється англійською мовою.

Делегація НТУ «ХПІ» також відвідала Бакинський державний університет (БДУ), 
Азербайджанський технічний університет (АзТУ), Азербайджанський державний університет нафти і промисловості (АДУНП). За підсумками візиту досягнуто домовленості в науково-освітній сфері та підписано Меморандум про взаєморозуміння. Делегація НТУ «ХПІ» відвідала Міністерство освіти Азербайджанської Республіки й Посольство України в Азербайджані, де обговорювали питання навчання азербайджанських студентів у НТУ «ХПІ», а також пріоритетні напрями співпраці українських й азербайджанських університетів. Значну вагу було приділено вивченню законодавчої бази, яка регулює питання в цій сфері.

У травні 2019 року делегація НТУ «ХПІ» відвідала Узбекистан. У межах візиту відбулась зустріч із керівництвом Ташкентського державного технічного університету імені Іслама Карімова, а також із представниками провідної фірми Inside-A, яка займається залученням узбецької молоді до навчання в харківському ЗВО. Під час цього візиту також відбулась зустріч із батьками узбецьких студентів, які вже навчаються в університеті.

Планомірна робота на ринку освітніх послуг привела до збільшення студентів, які вступили на основні факультети НТУ «ХПІ» 3 Азербайджану із 55 осіб у 2015 році до 80 осіб у 2019 році, 3 Єгипту із 4 осіб у 2015 році до 33 осіб у 2019 році, з Марокко 31 особи у 2015 році до 39 осіб у 2019 році, з Туреччини із 2 осіб у 2015 році до

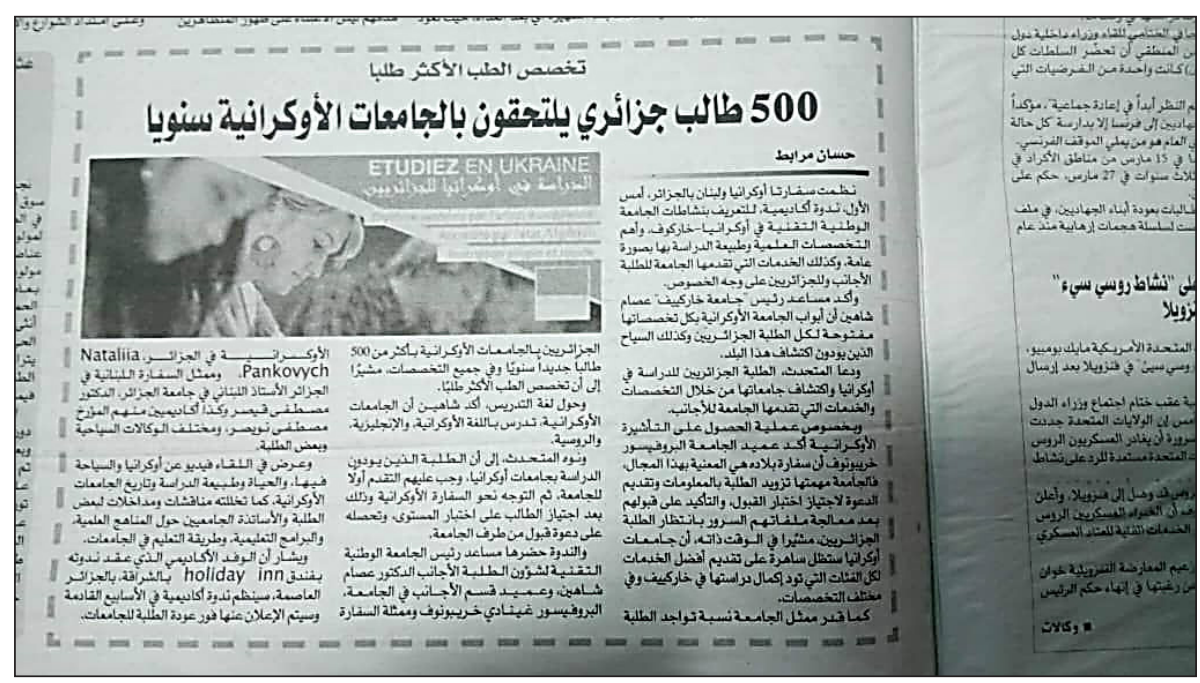

Рис. 1. Стаття у провідному алжирському арабомовному виданні «Аль-Шурук» під заголовком «Щороку 500 студентів з Алжиру їдуть навчатись в Україну». Номер від 06.04.2019 р.

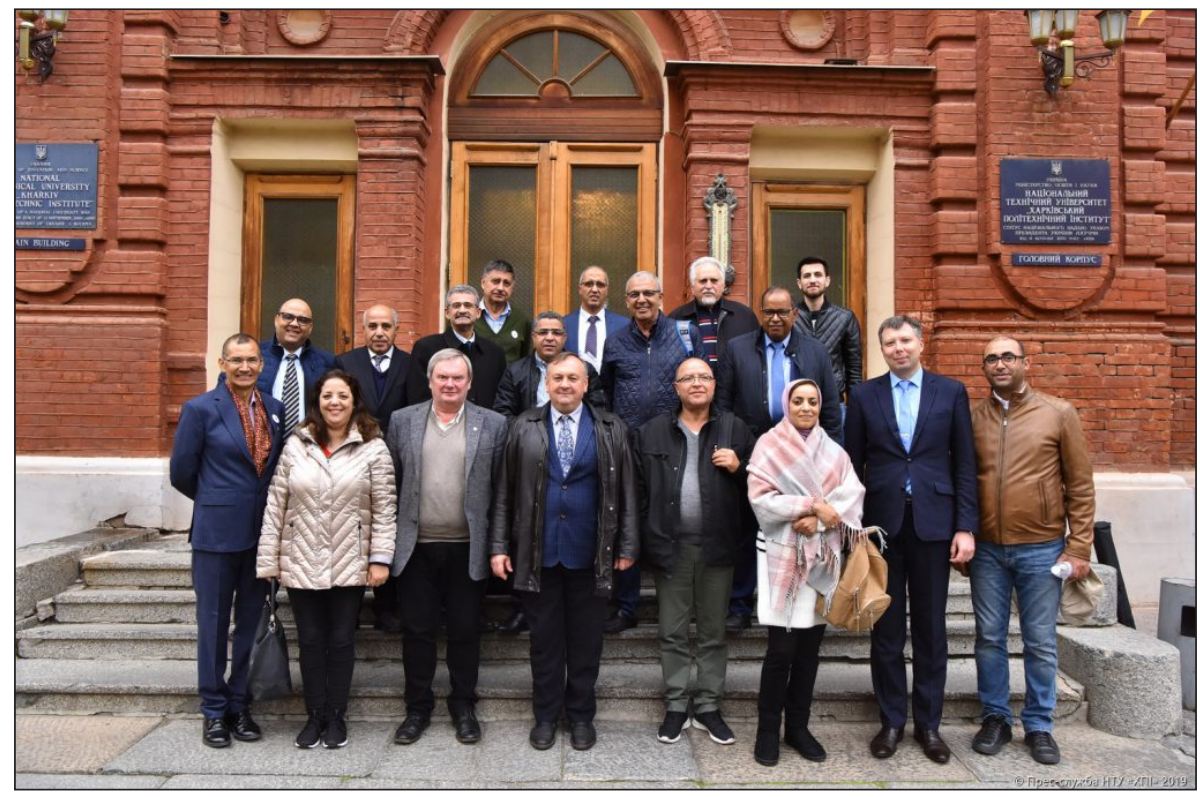

Рис. 2. Випускники НТУ «ХПІ» з Марокко відвідали свою Альма-матер 
60 осіб у 2019 році, з Узбекистану із 6 осіб у 2015 році до 65 осіб у 2019 році.

Загалом, за результатами 2018 року НТУ «ХПІ» посів перше місце серед технічних університетів України за кількістю вступників-іноземців. Отже, вдалось зупинити негативну тенденцію зниження загального контингенту студентів, яка була зумовлена початком бойових дій у 2014 році Загальний контингент іноземних студентів довузівської підготовки та основних факультетів та інститутів у НТУ «ХПІ» у 2019 році становив 1424 особи із 56 країн світу, що на 253 особи більше, ніж у 2018 році, та майже на 400 осіб більше, ніж у 2017 році.

Варто акцентувати увагу на діяльності освітнього центру «Німецького Технічного Факультету», який здійснює координацію співпраці між НТУ «ХПІ» та німецькими й австрійськими університетами-партнерами. Цей підрозділ організує безкоштовне вивчення німецької мови для студентів НТУ «ХПІ», допомагає студентам університету під час оформлення документів на навчання в університетах Німеччини й Австрії тощо. Завдяки його діяльності вдалось реалізувати Освітню програму «Німецькомовний інженер» (1-4 курс), організувати проведення лекцій із лекторами DAAD (Німеччина) та OeaD (Австрія), забезпечити роботу курсів німецької мови для іноземних студентів "Deutsch für Ausländer", курси німецької мови для викладачів НТУ «ХПІ» та літні платні курси для студентів «Інтенсивна німецька».

Наразі Центром виконуються договори Erasmus+ KA107 (2017-2021) iз FHWS (Німеччина) та договір між НТУ «ХПІ» та Магдебурзьким університетом ім. Отто-фон-Геріке (Німеччина). У 2019 році була проведена зустріч із представниками технічного університету TU Dresden для розробки програми міждисциплінарної літньої школи для студентів НТУ «ХПІ». Унаслідок цих заходів контингент слухачів освітнього центру збільшився із 28 осіб у 2017 році до 156 осіб у 2019.

Загалом, щодо програм обміну для українських студентів та викладачів, то навчання студентів за чинними програмами академічної мобільності охоплює різні за змістом види діяльності: навчальна; дослідницька; збір дослідницького матеріалу; експериментальна; робота в зарубіжних лабораторіях; вивчення зарубіжного досвіду видатних учених світу.

Ефективна система фінансування - не менш важливий фактор розвитку академічної мобільності в ЗВО. Це завдання можна вирішити шляхом залученню коштів, для чого необхідно налагодити роботу з пошуку грантів, програм кредитування й субсидування мобільності.

Як висновок, потрібно зауважити такі підсумки роботи університету з міжнародного співробітництва: підписано низку Договорів із закордонними ЗВО та фірмами; 40 освітніх і науково-дослідних міжнародних проєктів; 13 програм подвійного диплому із ЗВО Німеччини, Франції, Австрії, Польщі, Чехії, Болгарії, Кореї та Китаю; 3 проєкти Еразмус+ КА2 (розвиток потенціалу вищої освіти); 25 програм академічної мобільності за програмою Еразмус+ КА1 (семестрове навчання у країнах Свропи); діс Освітній центр «Німецький технічний факультет»; 461 людина виїхала за кордон (зокрема студенти, аспіранти, викладачі та науковці за різними напрямами); 145 студентів й аспірантів навчались та проходили стажування за кордоном, 74 з них - протягом більше 3-х місяців; щороку організовуються літні практики для студентів в Угорщині, Болгарії, Німеччині.

Висновки. Тож, підсумовуючи вищесказане, можна зробити висновок, що академічна мобільність студентів у зв'язку з модернізацією української освіти стає поширеною формою організації навчального процесу. Окрім того, відкритість кордонів створює для вітчизняних ЗВО не лише нові виклики, але й можливості. Хоча загалом теза про рух студентства до розвинених країн певною мірою знаходить своє підтвердження на практиці. Так, випускники програм подвійних дипломів між НТУ «ХПІ» та ЗВО із країн СС все частіше продовжують свою кар'єру за межами України (чи принаймні намагаються це зробити). А це створює нові виклики, які Україні ще належить прийняти.

\section{СПИСОК ВИКОРИСТАНИХ ДЖЕРЕЛ}

1. Altbach Philip G. Global Perspectives on Higher Education. JHU Press, 2016352 p.

2. MCU 2020. URL: http://www.magna-charta.org/magna-charta-universitatum/mcu-2020.

3. Living Values in Higher Education Institutions. URL: http://www.magna-charta.org/activities-and-projects/living -values-project.

4. Magna Charta Universitatum. URL: http://www.magna-charta.org/resources/files/the-magna-charta/english.

5. Wit Hans The Sorbonne and Bologna Declarations on European Higher Education H De Wit - International Higher Education, 2000. P. 8-9.

6. The Bologna Declaration of 19 June 1999: Joint declaration of the European Ministers of Education. URL: https://www.eurashe.eu/library/ modernising-phe/Bologna_1999_Bologna-Declaration.pdf. 
7. Realising the European Higher Education Area. Communique of the Conference of Ministers Responsible for Higher Education in Berlin. -19 September 2003. URL: https://enqa.eu/wp-content/uploads/2013/03/ BerlinCommunique1.pdf.

8. Галичин В. Академическая мобильность в условиях интернационализации образования. Минск : Университетская книга, 2009. 460 с.

9. Мартыненко О., Жукова Н. Управление академической мобильностью в вузах. Университетское управление: практика и анализ. 2008. № 1. С. 65-75.

10. Бринев Н., Чуянов Р. Академическая мобильность студентов как фактор развития образования. Пути развития высшего образования. Омск : ОГПУ, 2001. С. 31-34.

\section{REFERENCES}

1. Altbach Philip G. Global Perspectives on Higher Education. JHU Press, 2016352 p.

2. MCU 2020. URL: http://www.magna-charta.org/magna-charta-universitatum/mcu-2020.

3. Living Values in Higher Education Institutions. URL: http://www.magna-charta.org/activities-and-projects/living -values-project.

4. Magna Charta Universitatum. URL: http://www.magna-charta.org/resources/files/the-magna-charta/english.

5. Wit Hans The Sorbonne and Bologna Declarations on European Higher Education H De Wit - International Higher Education, 2000. P. 8-9.

6. The Bologna Declaration of 19 June 1999 : Joint declaration of the European Ministers of Education. URL: https://www.eurashe.eu/library/ bologna_1999_bologna-declaration-pdf/.

7. Realising the European Higher Education Area. Communique of the Conference of Ministers Responsible for Higher Education in Berlin. 19 September 2003. URL: https:/enqa.eu/wp-content/uploads/2013/03/ BerlinCommunique1.pdf.

8. Halychyn V. Akademycheskaia mobylnost v uslovyiakh ynternatsyonalyzatsyy obrazovanyia. Academic mobility in the context of education internationalization. M. : Unyversytetskaia knyha, 2009. 460 p. [In Russian].

9. Martynenko O., Zhukova N. Upravlenye akademycheskoi mobylnostiu v vuzakh. Universities Academic Mobility Management. University Management : Practice and Analysis. 2008. № 1. P. 65-75. [In Russian].

10. Brynev N., Chuianov R. Akademycheskaia mobylnost studentov kak faktor razvytyia obrazovanyia [Academic mobility of students as a factor of the education development]. Ways of higher education development. Omsk, 2001. P. 31-34. [In Russian]. 